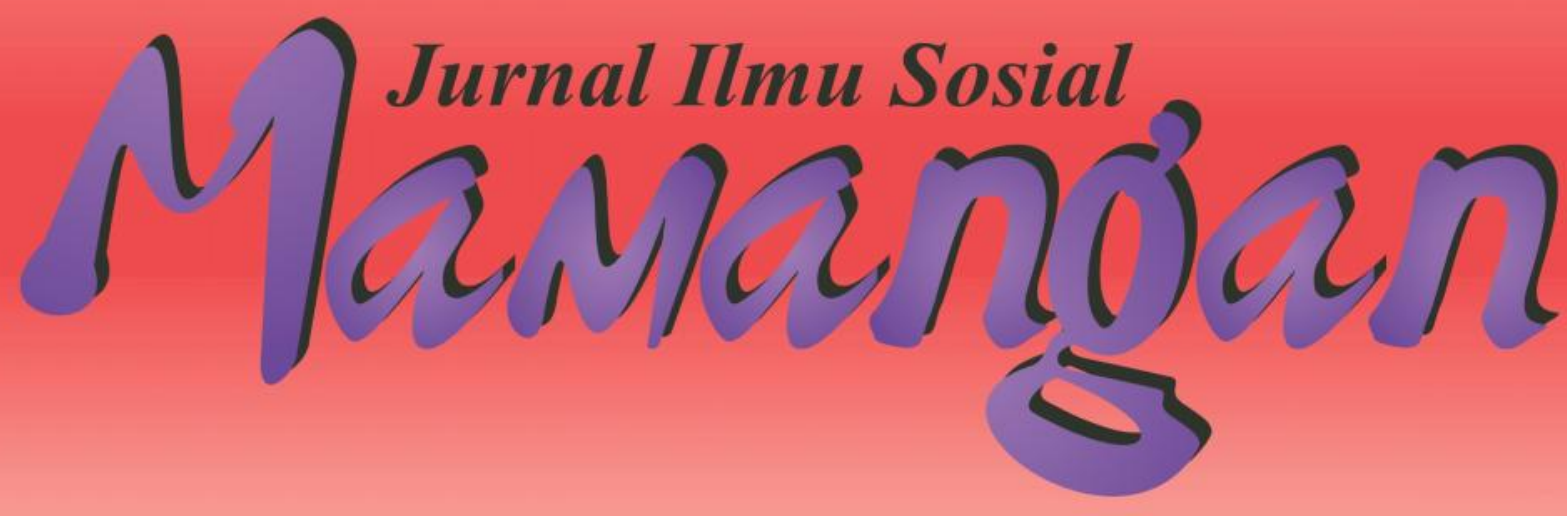

Peran Perantau Terhadap Pembangunan Di Jorong Galogandang, Nagari III Koto Kec. Rambatan, Kab. Tanah Datar Vivi Emita, Zusmelia \& Marleni

Julo-Julo Tani Buruh Perempuan Jorong Patamuan, Nagari Talu Kecamatan Talamu Kab. Pasaman Barat Sriwahyuni, Zusmelia \& Delmira Syafirini

Dari Petani Ke Penambang; Perubahan Sosial Ekonomi Di Jorong Koto Panjang, Nagari Limo Koto, Kabupaten Sijunjung

Melta Ardila Sari, Ardi Abbas \& Darmairal Rahmad

Strategi Masyarakat Multikultural Pasaman Barat Menghindari Konflik

Elly Kristin Debora, Dian Kurnia Anggreta \& Faishal Yasin

Konflik Sopir PO. Mitra Kencana Vs Pengemudi Betor di Air Bangis, Kab. Pasaman Barat

Helma Frida, Witrianto \& ZusneliZubir

Konflik Tanah Ulayat Antara Kamanakan Malakok VS Niniak Mamak Suku Tobo Di Nagari Padang Laweh, Kec. Koto VII, Kab. Sijunjung Welda Ningsih, Dian Kurnia Anggreta \& Rinel Fitlayeni 


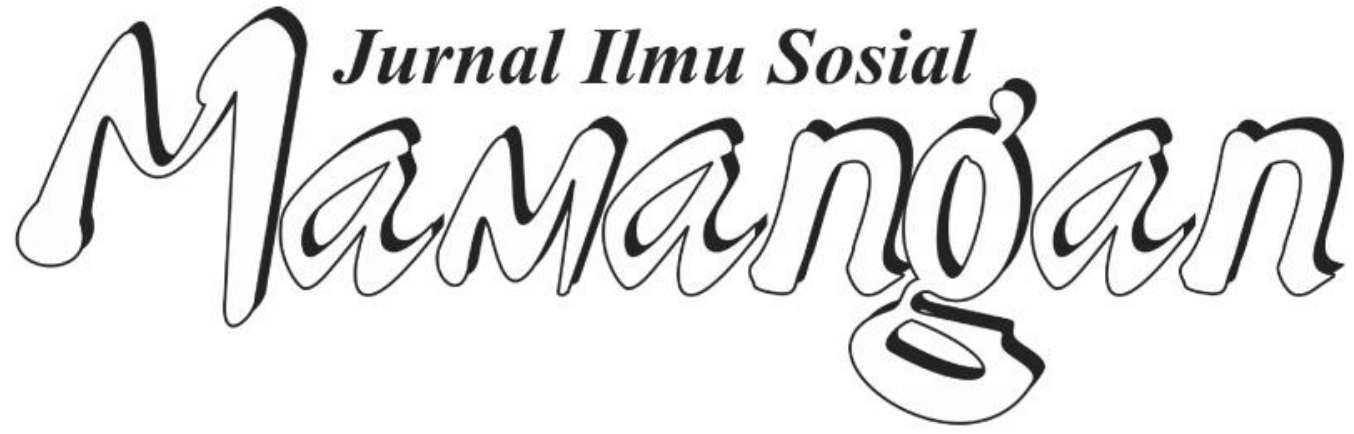




\section{Mitra Bestari}

Prof. Dr. Afrizal, MA. (FISIP, Unand Padang)

Dr. A. Latief Wiyata, M. Si. (Universitas Jember, Jember)

Prof. Dr. Badaruddin, M. Si. (FISIP, USU Medan)

Dr. Fikarwin Zuska, M. Si. (FISIP, USU Medan)

Nurus Shalihin, M. Si., Ph.D. (Fak. Ushuluddin IAIN Imam Bonjol Padang)

Dr. Semiarto A. Purwanto, M. Si. (FISIP, UI Jakarta)

Dr. Wahyu Wibowo, M. Si. (Universitas Nasional, Jakarta)

\section{Dewan Redaksi}

Dr. Zusmelia, M. Si.

Dr. Maihasni, M. Si.

Adiyalmon, S. Ag., M. Pd.

Firdaus, S. Sos., M. Si.

\section{Pemimpin Redaksi}

Firdaus, S. Sos., M. Si.

\section{Anggota Redaksi}

Dian Kurnia Anggreta, S. Sos., M. Si.

Rinel Fitlayeni, S. Sos., MA.

Surya Prahara, SH.

ISSN: 2301-8496

\section{Alamat Redaksi:}

Laboratorium Program Studi Pendidikan Sosiologi, STKIP PGRI Padang

Jl. Gunung Pangilun, Padang

Email: redaksimamangan@yahoo.com

Penerbit :

Program Studi Pendidikan Sosiologi, STKIP PGRI Padang

\section{Contac person :}

Firdaus (Hp. 085263881221/Email : daus gila@yahoo.com) 


\section{DAFTAR ISI}

Peran Perantau Terhadap Pembangunan Di Jorong Galogandang, Nagari III Koto Kec. Rambatan, Kab. Tanah Datar

Vivi Emita, Zusmelia \& Marleni

Julo-Julo Tani Buruh Perempuan Jorong Patamuan, Nagari Talu Kecamatan Talamu Kab. Pasaman Barat

Sriwahyuni, Zusmelia \& Delmira Syafirini

Dari Petani Ke Penambang; Perubahan Sosial Ekonomi Di Jorong Koto Panjang, Nagari Limo Koto, Kabupaten Sijunjung

Melta Ardila Sari, Ardi Abbas \& Darmairal Rahmad

Strategi Masyarakat Multikultural Pasaman Barat Menghindari Konflik

Elly Kristin Debora, Dian Kurnia Anggreta \& Faishal Yasin

Konflik Sopir P0. Mitra Kencana Vs Pengemudi Betor di Air Bangis, Kab. Pasaman Barat

Helma Frida, Witrianto \& Zusneli Zubir

Konflik Tanah Ulayat Antara Kamanakan Malakok VS Niniak Mamak Suku Tobo Di Nagari Padang Laweh, Kec. Koto VII, Kab. Sijunjung Welda Ningsih, Dian Kurnia Anggreta \& Rinel Fitlayeni. 


\title{
STRATEGI MASYARAKAT MULTIKULTURAL PASAMAN BARAT MENGHINDARI KONFLIK
}

\author{
Elly Kristin Debora, Dian Kurnia Anggreta \& Faishal Yasin \\ Sekolah Tinggi Keguruan dan Ilmu Pendidikan (STKIP) PGRI Sumatera Barat
}

\begin{abstract}
Nagari Koto Baru Kecamatan Luhak Nan Duo Kabupaten Pasaman Barat Sumatera Barat, a district with multicultural society, consists of many ethnics which have different cultural each other's. Despite of many ethnics in Nagari Koto Baru, it doesn't make any conflicts occurred. This research using qualitative method (questionnaires and interviews) and focused to the reasons and strategies of people in Koto Baru to avoid conflicts in their societies. The results showed that why people in Nagari Koto Baru avoid conflicts cause of solidarity and marriage factors. In the manner of marriage, people become closer and higher solidarity among many ethnics. And the strategies to avoid conflicts by means of cooperation, accommodation and assimilation. Cooperation many ethnics, accommodation (the efforts to solve conflicts) and assimilation (by marriage among many ethnics) are appropriate strategies to avoid conflicts.
\end{abstract}

Keyword : Strategy, Management Conflict, Multicultural Society

\begin{abstract}
ABSTRAK
Masyarakat Nagari Koto Baru adalah masyarakat yang multikultural yang terdiri dari berbagai suku bangsa, dimana setiap suku bangsa memiliki kebudayaaan yang berbeda.Meskipun masyarakat nagari Koto Baru memiliki keanekaragaman suku bangsa, namun di Nagari Koto Baru tidak pernah terjadi konflik. Dalam penelitian ini yang akan diteliti adalah apa penyebab dan bagaimana strategi masyarakat multikultural di Nagari Koto Baru di Kecamatan Luhak Nan Duo Kabupaten Pasaman Barat menghindari konflik. Penyebab masyarakat multikultural di Nagari Koto Baru di Kecamatan Luhak Nan Duo Kabupaten Pasaman Barat menghindari konflik disebabkan oleh dua faktor yaitu faktor solidaritas dan faktor perkawinan. Solidaritas yang terbangun diantara berbagai suku meminimalkan kemungkinan terjadinya konflik. Dengan perkawinan, juga merupakan salah satu cara terhindar dari konflik. Sementara itu, strategi yang dilakukan oleh masyarakat Nagari Koto Baru dalam menghindari konflik adalah dengan cara melakukan suatu proses kerjasama, akomodasi dan asimilasi. Akomodasi yang merupakan upaya damai untuk mencapai penyelesaian dari suatu pertikaian dan asimilasi dengan jalan melakukan perkawinan antar sukubangsa yang satu dengan yang lain, disamping meningkatkan kerjasama, menjadi strategi yang jitu bagi masyarakat Nagari Koto Baru untuk menghindari konflik.
\end{abstract}

Kata Kunci : Strategi, Manajemen Konflik, Masyarakat Multikultural 


\section{PENDAHULUAN}

Indonesia merupakan negara yang memiliki masyarakat multikultural yang terdiri dari berbagai suku, dimana setiap suku memiliki kebudayaan yang berbeda. Kelompok etnik atau suku bangsa adalah suatu golongan manusia yang anggotaanggotanya mengidentifikasi dirinya dengan sesama biasanya berdasarkan garis keturunan yang dianggap sama. Identitas suku pun ditandai oleh pengakuan dari orang lain akan ciri khas kelompok tersebut dan oleh kesamaan budaya, bahasa, agama, perilaku atau ciri-ciri biologis (Setiadi \& Kolip, 2011).

Klasifikasi dari aneka warna suku bangsa di Indonesia biasanya masih berdasarkan lingkaran hukum adat yang mula-mula disusun oleh Van Vallenhoven. Sistem tersebut membagi Indonesian ke dalam 19 daerah yaitu Aceh, Sulawesi Selatan, Gayo-Alas dan Batak, Ternate, Nias, dan Batu, Ambon Maluku, Minangkabau, Kepulauan Barat Daya, Mentawai, Papua (irian), Sumatra Selatan, Timor, Enggano, Bali dan Lombok, Melayu, Jawa Tengah dan Timur, bangka dan Belitung, Surakarta dan Yogyakarta, kalimantan, Jawa Barat, SangirTaulad Gorontalo, serta Toraja (Fathoni, 2006).

Dimana sekitar 210 juta orang penduduk indonesia sulit diketahui secara pasti distribusi jumlah dari masing-masing suku bangsa. Terakhir kalinya, sensus pensusuk yang memuat item suku bangsa adalah yang dilakukan oleh pemerintah kolonial Hindia Belanda yang hasilnya dimuat dalam Volkstelling (1930).Sensus Penduduk Indonesia yang dilakukan pada tahun 1970 dan dala dasawarsa berikutnya, tidak mencantumkan items suku bangsa. Mengingat hal tersebut, ada kesulitan untuk mengetahui secara pasti laju pertumbuhan penduduk berdasarkan suku bangsa dan distribusi mereka (Koentajaraningrat, 1996).

Walaupun demikian, ada pula berbagai usaha untuk mengetahui jumlah suku bangsa, antara lain statistik Hindia Belanda menggambarkan besarnya persentase berbagai suku Bangsa di Indonesia pada tahun 1930 bahwa Suku Bangsa Jawa mencapai (47,02\%), sunda $(14,53 \%)$, Madura (7,28\%), minangkabau ( $3,36 \%)$, Bugis ( 2,59\%), Batak (2,04\%), Bali (1,88\%), betawi (1,66\%), Melayu (1,61\%), Banjar
(1,52\%), Aceh (1,41\%), Palembang (1,30\%), Sasak (1,12\%), Dayak (1,10\%), Makassar (1,09\%), Toraja $(0,94 \%)$, dan Suku Bangsa lainnya (9,54\%), dan orang Cina $(2,7 \%)$. Sementara itu, dikalangan para pakar masih terdapat perbedaan dalam mengklasifikasikan penduduk di Indonesia ke dalam suatu konsep suku bangsa (Nasikun, 1984).

Keanekaragaman suku bangsa disetiap daerah cenderung menimbulkan konflik karena adanya perbedaan kebudayaan, di Indonesia sering timbul konflik antar suku bangsa dengan pemicu konflik yang berbedabeda yaitu diantaranya, konflik antar suku Melayu, suku Dayak, dengan suku madura yang berada di Kabupaten Sambas Kalimantan Barat yang sudah berlangsung sejak tahun 1952-an hingga april 1999. Pemicu terjadinya konflik di Sambas yaitu karena orang-orang Madura di Sambas selalu menonjolkan kesukubangsaan Maduranya bukan orang-perorangannya.Mereka selalu hidup dan bekerja dalam kelompokkelompok sebagai orang madura, membangun solidaritas sosial diantara sesama mereka dan bila terjadi persengketan antara orang madura dengan orang melayu atau Dayak maka persengketan tersebut adan selalu diselesaikan oleh kelompok Madura yang bersangkutan.

Kesukubangsaan pada orang Madura di Sambas, dalam bentuk kelompok dan solidaritas sosial orang Madura, adalah merupakan acuan utama dari keberadaan dan kelangsungan hidup bagi mereka. Disamping itu, orang-orang dan kelompok Madura mempunyai kecenderungan untuk menyelesaikan berbagai masalah dan perseketaan dengan cara ancama dan kekerasan. Tanpa disadari oleh semua anggota suku bangsa yang ada di Sambas., dengan cara ancaman dan kekerasan inilah maka secara bertahap kebudayaan dominan Melayu Maupun Dayak di tempat-tempat umum di Sambas digeser dan diganti oleh dominasi kekerasan dari kebudayaan Madura. Corak hubungan antara orang Madura dengan orag Melayu dan Dayak di Sambas diwarnai oleh kekerasan, dan kekerasan ini adalah kekerasan kategorikal atau golongan, sehingga pada waktuterjadi konflik antara Melayu lawan Madura dan Dayak lawan Madura, yang ada adalah konfik 
antar golongan askriptif dengan segala atributnya untuk secara kekerasan dihancurkan. Konflik-konflik berdarah yang terjadi di Sambas, Ambon, Poso atau Sampit adalah konflik antar sukubangsadan bukannya konflik komunal sebagaimana yang telah dinyatakan(Suparlan, 2004).

Gambaran konflik yang ada di Indonesia tersebut sangat perlu adanya manajemen konflik agar konflik tidak sampai pada tahap eskalasikonfrontasi. Jika diendalikan, konflik bisa berkembang menjadi konflik distruktif, dimana masingmasing pihak akan memfokuskan perhatian, tenaga, dan fikiran, serta sumber-sumber organisasi bukan untuk mengembangkan produktifitas, tetapi untuk merusak dan menghancurkan lawan konflik mereka. Hal ini berarti merusak potensi produktifitas mereka, akibatnya kinerja mereka akan menurun sehingga menurunkan produktifiatas sistem social (Wirawan, 2010).

Nagari Koto Baru Kecamatan Luhak Nan Duo Kabupaten Pasaman barat merupakan salah satu daerah yang memuliki masyarakat multikultural dengan keberagaman suku bangsa. Suku bangsa yang terdapat di Nagari Koto Baru Kecamatan Luhak Nan Duo Kabupaten Pasaman Barat diantaranya suku asli minangkabau dan suku pendatang yaitu suku suku Jawa, Sunda, Batak dan Mandailing.

Meskipun kabupeten Pasaman Barat memiliki suku bangsa yang beranekaragam namun di daerah ini tidak pernah terjadi konflik. Seperti di kota Binjai yang juga beragam dan nyaris tidak berkonflik (Firdaus, 2012), di nagari Koto Baru, Pasaman Barat juga tidak terjadi konflik. Pertanyaannya yang menjadi rumusan masalah dalam penelitian ini adalah bagaimana Masyarakat Multikultural di nagari Kotobaru menghindari konflik dalam keberagaman? Artikel ini mendeskripsikan strategi masyarakat multikultural Nagari Koto Baru kecamatan Luhak Nan Duo Kabupaten Pasaman Barat dalam menghindari konflik

\section{TINJAUAN PUSTAKA}

Fungsional struktural memiliki pandangan bahwa masyarakat merupakan suatu sitem yang terdiri dari bagian-bagian atau elemen-elemen yang saling berkaitan dan saling menyatu dalam keseimbangan.Asumsi dasarnya adalah bahwa setiap struktur dalam sistem sosial, fungsional terhadap struktur yang lain (Ritzer, 2012).Suatu funsi adalah suatu kompleks kegiatan-kegiatan yang diarahlan kepada pemenuhan suatu kebutuhan sistem itu. Merujuk pada definisi tersebut Pearson membagi empat imperatif fungsional yang perlu bagi semua sistem yaitu AGIL, agar dapat lestari suatu sistem harus melakukan keempat funsi tersebut yaitu Adaptation (A), suatu sistem harus mengatasi kebutuhan mendesak yang bersifat situasional eksternal. Selain itu harus beradaptasi dengan lingkungan dan kebutuhankebutuhannya., Goal attainment (G), suatu sistem harus mendefinisikan dan mencapai tijuan utama, integration (I), suatu sistem harus mengatur antar hubungan bagianbagian dari komponennya. Ia juga harus mengelolah hubungan antara tiga imperatif fungsional lainnya. (A, G, L), dan Latency (L), suatu sistem harus menyediakan, memelihara, dan memberbaharui baik motivasi para individu maupun pola-pola budaya yang menciptakan dan menompang motivasi itu (Ritzer, 2012).

\section{METODE PENELITIAN}

Pendekatan penelitian ini adalah kualitatif. Penelitian ini bertipekan deskriptif yaitu berusaha untuk menggambarkan dan menjelaskan terperinci tentang masalah yang akan diteliti. Dalam penelitian ini peneliti menggunakan mekanisme snowballing, alasannya karena penelitian yang akan dilakukan tidak menetapkan kriteria tertentu dimana informan yang akan diteliti. Peneliti akan melakukan wawancara berulang-ulang sampai penelitian tersebut terjawab. Data yang diambil pada penelitian ini adalah data secara primer, dengan metode pengumpulan data pada penelitian ini yaitu dari observasi, wawancara, dan dokumen. Analisis ata dalam penelitian ini menggunakan strategi analisi data yang telah dikemukakan oleh Seiddle, dengan alasan analisis data tersebut merupakan sebuah proses yang harus dilakukan dengan penelitian kualitatif.

\section{FAKTOR PENGHAMBAT KONFLIK}

Penyebab masyarakat multikultural di Nagari Koto Baru menghindari konflik yaitu 
disebabkan karena dua faktor diantaranya adalah faktor silidaritas masyarakat Nagari Kota Baru yang sangat tinggi dan faktor perkawinan antara suku bangsa yang satu dengan suku bangsa yang lain dalam kata lain suku bangsa yang berbeda.

\section{Solidaritas Antar Suku Bangsa}

Suku bangsa di Nagari Koto Baru memiliki solidaritas yang sangat tinggi dimana meskipun Nagari Koto Baru memiliki keanekaragaman suku bangsa dengan perbedaan kebudayaan, masyarakatnya tidak individualis dan selalu bersama-sama dalam setiap melakukan kegiatan baik itu kegiatan yang ssifatnya bersama maupun kegiatan yang sifatnya menyangkut tentang suku bangsa tertentu. Masyarakat Nagari Koto Baru juga tidak pernah mementingkan eksistensi suku bangsa mereka masingmasing.

Masyarakat di Nagari Koto Baru beranggapan bahwa penyebab terhindarnya konflik di Nagari Koto Baru karena setiap suku bangsa yang ada di nagari Koto Baru sama saja, dimana mereka beranggapan masyarakat di Nagari Koto Baru merupakan salah satu bentuk model indinesia mini yang menggunakan aturan kehidupan nasional. Kehidupan nasional merupakan pencerminan ketahanan nasioanal yang didasarkan oleh landasan idiil pancasila, landasan konstitusional UUD 1945, dan landasan visional wawasan nusantara. Ketahanan nasional adalah kondisi yang harus dimiliki dalam semua aspek kehidupan bermasyarakat , berbangsa dan bernegara dalam wadah Negara Kesatuan Republik Indonesia (Sumarsono, 2005).

Berdasarkan penjelasan mengenai aturan kehidupan nasional tersebut, mencerminkan bahwa masyarakat multikultural di Nagari koto Baru tidak hanya mementingkan eksistensi suku bangsa masing-masing, sehingga masyarakat Minangkabau memahami bahwa suku bangsa lain yang datang ke Kabupaten Pasaman Barat Khususnya di Nagari Koto Baru tersebut sebagai suku bangsa yang memiliki sikap hidup nasional karena suku bangsa lain yang merupakan pendatang di Nagari Koto Baru mampu bersatu dengan suku bangsa Minangkabau untuk mewujudkan ketahanan Nasional yang berada di Nagari Koto baru. Penjelasan tersebut tergambar dari pernyataan salah satu informan, yaitu Bapak Zainal Abidin (Minangkabau), 53 tahun informan yang lain juga menjelakan hampir sama. Pernyataan Bapak Zainal Abidin adalah sebagai berikut,"kami di Nagari Koto Baru tidak ada yang mementingkan suku bangsa masing-masingkami memakai aturan Indonesia saja. Apalagi di Nagari ini lebih banyak pendatang dari pada masyarakat Minangkabau jadi kami memutuskan untuk ikut aturan Indonesia saja yaitu hidup dengan kehidupan nasional biar kami bisa bersatu sama suku bangsa pendatang di Nagari Koto Baru ini".

\section{Pernikahan Antar Suku}

Keanekaragaman suku bangsa yang ada di Nagari Koto Baru juga Menyebabkan adanya perkawinan beda suku bangsa, namun tidak keseluruhan suku bangsa yang ada di Nagari Koto Baru yang melakukan perkawinan berbeda suku bangsa. Perbedaan perkawinan atau suku bangsa yang terjadi di Nagari Koto Baru, terjadi antara suku Minangkabau dengan suku Jawa, suku Minaangkabau dengan suku Sunda, suku Minangkabau dengan suku Mandailing, suku Jawa dengan suku Sunda, dan suku suku Jawa dengan suku Mandailing.

Perkawinan tersebut dilakukan dengan menggunakan tradisi mereka masing-masing seperti perkawinan yang dilakukan oleh suku Minangkabau menikah dengan suku Jawa maka mereka akan melakukan dua tradisi di tempat mempelai laki-laki adat Jawa dan di tempat perempuan menggunakan adat Minangkabau. Tradisi ini tidak akan dilakukan apabila tidak ada musyawarah bersama antara keluarga beras antara kedua belah pihak bahwa tradisi mana yang akan dilakukan oleh kedua belah pihak. Menjelaskan tersebut diperkuat oleh pernyataan salah satu informan suku bangsa Minangkabau yang menikah dengan suku bangsa Jawa ibu Ekin (Minangkabau) 29 tahun yang menyatakan bahwa,"meskipun suami 
saya orang Minangkabau tapi kami bisa menggunakan tradisi Jawa untuk melaksanakan perkawinan, namun tradisi itu bisa kami lakikan apabilan ada persetujuan antara pihak keluarga besar dari kami dan pihak keluarga besar dari suami saya. Sebelum melakukan prosesi perkawinan kami melakukan pertemuan untuk mengadakan musyawarah bersama agar tidak ada kesalahpahaman diantara keluarga yang akan disatukan, musyawarah tersebut akan menghasilkan kesepakatan bersama yaitu menggunakan dua tradisi, dimana tradisi Minangkabau ditempatkan keluarga suami saya".

Perkawinan yang dilakukan oleh suku bangsa yang berbeda juga merupakan salah satu penyebab masyarakat multikultural dalam menghindari konflik, karena dengan adanya perkawinan yang berbeda suku bangsa akan dapat mengintegrasikan antar suku banga yang satu dengan suku bangsa yang lain, hal ini disebabkan karena adanya sifat saling menghargai dan segan-menyegani antara suku yang melakukan perkawinan tersebut.

\section{STRATEGI MENGHINDARI KONFLIK}

Konsep masyarakat multikultural dalam artian yang lebih luas, menurut Wahyu (2004) relatif baru muncul sekitar tahun 1970-an. Gerakan multikultural muncul pertama kali di Kanada dan kemudian diikuti oleh Amerika Serikat, Inggris, Jerman dan Australia. Kemunculan multikultural di Kanada dilatari oleh kondisi kenegaraan Kanada yang didera konflik yang disebabkan oleh hubungan antar warga negara. Masalah tersebut meliputi hubungan antar suku bangsa, agama, ras dan aliran politik yang terjebak pada dominan dan tidak dominan. Konflik tersebut kemudian mampu diselesaikan dengan digagasnya konsep masyarakat multikultural yang esensinya adalah kesetaraan, menghargai hak budaya komunitas dan demokrasi (Firdaus, 2006).

Masyarakat multikultral menghindari konflik dalam penelitian ini diartikan bagaimana potensi konflik yang ada pada masyarakat multikultural tersebut tidak berlanjut kepada konflik manifes. Dalam hal ini ada strategi yang mereka gunakan sehingga konflik laten itu tidak berkembang menjadi konflik manifes.Strategi masyarakat multikultural di Nagari Koto Baru dalam menghindari konflik yaitu diawali dengan bagaimana masyarakat asli Minangkabau memahami, meneriama, dan mampu menghargai setiap kebudayaan dan tradisi yang dibawa oleh suku bangsa pendatang ke Nagari Koto Baru. Hal ini telah dibuktikan bahwa meskipun seluruh suku bangsa pendatang yang mendominasi masih tetap menggunakan kebudayaan dan tradisi mereka masing-masing namun suku Minangkabau masih menggunakan kebudayaan dan tradisi mereka dan sebaliknya, adapun yang dipahami, diterima, dan dihargai adalah kebudayaan dan tradisi suku bangsa yaitu (1) Suku Bangsa Minangkabau (2) Suku Bangsa Batak, (3) Suku Bangsa Jawa, (4) Suku Bangsa Sunda, dan (5) Suku Bangsa Mandailing.

\section{Kebudayaan \& Tradisi Minangkabau}

Sebagai suku asli masyarakat minangkabau memiliki identitas dan ciri khas kebudayaan dan tradisi yang sangat berbeda dengan kebudayaan dan tradisi yang dimiliki oleh suku pendatang yang ada di Nagari Koto Baru eperti kebudayaan dan tradisi suku Batak, suku Sunda dan Suku Mandailing. Meskipun kebudayaan dan tradisi suku Minangkabau sangat berbeda dengan kebudayaan dan tradisi suku bangsa lainnya namun setiap keputusan dan kesepakatan yang disesuaikan dengan kebudayaan dan tradisi Minangkabau tetap diterima dan dijalankan oleh suku bangsa lain. Penjelaan tersebut diperkuat dengan pernyataan informan ibu Santi (Jawa) 35 tahun menyatakan bahwa,
"kami sadar kalau kami hanya pendatang di sini jadi setiap peraturan yang ditetapkan di Nagari Koto Baru ini tetap kami hargai dan kami patuhi, meskipun peraturan yang ditetapkan di nagari ini selalu disesuaikan dengan tradisi atau kebiasaan budaya Minangkabau, namun peraturan yang ditetapkan itu tidak hanya ditetapkan sepihak oleh suku Minangkabau meskipun pemimpin nagari Koto Baru orang minang tetap setiap keputusan dimusyawarahkan bersama dalam 
rapat nagari yang dihadiri oleh seluruh suku bangsa yang mendominasi di Nagari Koto Baru ini".

Kebudayaan dan tradisi Minangkabau yang sangat kental dengan falsafah islamnya tidak berpengaruh terhadap suku bangsa yang memiliki keyakinan yang berbeda dengan suku minang kabau untuk menerima dan menghargai setiap peraturan yang disesuaikan dengan kebudayaan Minangkabau dan juga ditetapkan bersama melalui musyawarah mufakat oleh seluruh suku bangsa yang mendominasi dan memiliki jabatan penting dalam Nagari Koto Baru tersebut.

Selanjutnya kebudayaan yang sangat menonjol pada suku Minangkabau adalah bahasa yang digunakan oleh masyarakat Minangkabau, dimana bahasa yang digunakan oleh suku minangkabau dalam melakukan interaksi sehari-hari adalah bahasa daerah mereka yaitu bahasa Minangkabau dan bahasa ini juga dipelajari oleh suku bangsa lainnya sehingga seluruh suku bangsa yang ada di Nagari koto Baru memahami bahasa yang digunakan oleh suku Minangkabau meskipun sebagian daru suku bangsa lain sulit untuk berbicara dengan menggunakan bahasa minangkabau.

Penjelasan tentang peraturan yang telah ditetapkan di Nagari Koto Baru yang disesuaikan dengan falsafah islam menggambarkan bahwa kebudayaan suku minangkabau dari segi sistem religinya masyarakat Minangkabau memiliki keyakinan atau menganut agama Isalm, meskipun suku Minangkabau beragama Islam suku tersebut sangat menghargai suku bangsa yang memiliki pebedaan agama dengan suku mereka, dimana suku minangkabau tetap mendukung setiap kegiatan yang dilakukan oleh suku bangsa yang beragama Kristen dengan memberikan keaman dan kenyamanan dalam setiap kegiatan yang dilakukan.

Unsur kegiatan Minangkabau ditinjau dari kesenian juga sangat dapat diterima dan juga dipelajari oleh suku bangsa lain, hal ini tergambar dari setiap penampilan kesenian yang ditampilkan, disetiap acara-acara pernikahan, khitanan, dan acara turun mandi serta acara-acara resmi yang ada di Nagari Koto Baru tidak hanya suku bangsa Minangkabau yang menampilkan pertunjukan kesenian yang mereka miliki namun suku bangsa lainnya turut menampilkan setiap kesenian yang ada di Minangkabau.

\section{Kebudayaan dan Tradisi Suku Batak}

Suku bangsa Batak merupakan salah satu suku pendatang di Nagari Koto Baru, suku Bangsa Batak mempunyai jumlah yang cukup banyak di nagari Koto Baru ini, yaitu dengan jumlah kuranglebih 20 persen dari keseluruhan jumlah penduduk termasuk suku bangsa Minangkabau yang merupakan penduduk asli di Nagari Koto Baru. Suku bangsa Batak memiliki identitas dan ciri khas tersendiri dalam segi kebudayaan dan tradisi mereka, di Nagari Koto Baru ciri khas dan identitas ini masih tetap ada, namun tidak keseluruhan kebudayaannya dan tradisi suku Batak tetap ada di Nagari Koto Baru karena suku bangsa Batak harus tetap menghargai dan mengikuti peraturan yang lebuh ditetapkan bersama di Nagari tersebut.

Kebudayaan dan tradisi yang masih digunakan di Nagari Koto Baru yang pertama, bahasa yang digunakan oleh suku Batak di daerah asalnya masih tetap digunakan namun dgunakan pada sesama suku Batak dan dengan suku bangsa lainnya masyarakat Batak menggunakan Bahasa Indonesia. Meskipun bahasa yang digunakan oleh suku Batak untuk berbicara dengan suku bangsa lainnya adalah Bahasa Indonesia namun logat yang digunakan suku batak tetap sama yaitu logatnya yang keras sehingga terkesan kasar, hal ini tidak menyebabkan masyarakat multikultur di Nagari Koto Baru berkonflik karena suku bangsa lain di nagari tersebut bisa memahami logat bahasa yang digunakan oleh suku Batak tersebut.

Kedua, sistem religi, suku Batak di Nagari Koto Baru beragama Kristen Protestan dan Kristen Katolik, dalam kehidupan mereka tetap hidup aman dan 
damai baik itu dalam peribadatan dan melakukan kegiatan agamanya. Perbedaan agama tersebut tidak menjadikan suku bangsa lain memenintimidasikan suku Batak dan suku Batak juga tidak merasa teralienasi karen suku bangsa lain dapat menerima dan menghargai kepercayaan yang dianut oleh suku Batak.

Ketiga kesenian, kesenian yang dimiliki oleh suku Batak masih ditampilkan di Nagari Koto Baru namun tidak keseluruhan kesenian yang ditampilkan di Nagari Koto Baru, kesenian yang ditampilkan adalah tari Tor-Tor, dimana tarian ini ditampilkan pada setiap acara perkawinan suku Bangsa Batak dan setiap acara-acara resmi di Nagari Koto Baru bahkan acara resmi kabupaten, pernyataan tersebut diperkuat ole bapak Samosir (Batak), 53 tahun yag menyatakan bahwa, " salah satu kelebihan dari Nagari Koto Baru ini adalah masyarakatnya yang sangat menghargai setiap tradisi dan kebudayaan yang kami bawa dari daerah asal seperti contohnya tradisi perkawinan kami, bahasa juga jika bertemu dengan sesama suku kami kami dapat menggunakan bahasa kami tanpa bersembunyi-sembunyi hanya saja kami tetap menghargai mereka dengan menggunakan Bahasa Indonesia jika berbicara dengan suku lain, selain basa kebudayaan yang kami miliki tetap ada seperti agama kami yang berbeda dengan mereka tetap dihargai oleh suku bangsa lainnya khususnya suku Minangkabau yang merupakan suku asli di Nagari ini dan juga dalam kesenian tarian Tor-Tor yang kami miliki tetap ditampilkan di setiap acara-acara resmi Nagari maupun Kecamata".

Keempat, tradisi perkawinan, suku bangsa Batak masih tetap menggunakan adat-adat perkawinan yang ada di daerahnya, dimana tradisi perkawinan yang dilakukan oleh suku Batak yaitu diawali dari diadakannya upacara mukul pada malam harinya kemudian empat sampai tujuh hari kedua penganten melakukan kunjungan-kunjungan kerumah orang tua sang istri dan ke kunjungan kerumah sang suami, setelah dilakukan kunjungan-kunjungan tersebut yang terakhir adalah upacara perkawinan yang dilakukan di gereja. Setiap proses tradisi perkawinan suku Batak hanya dihadiri oleh kelompok mereka yang sama-sama suku Batak. Konstribusi suku bangsa lain dalam membantu suku Batak pada acara perkawinannya yaitu hanya sebatas menghadiri resepsi perkawinan suku bangsa Batak dan membantu memasak, dimana dalam proses memasak suku batak memisahkan makanan antara masakan suku mereka sendiri dengan suku bangsa lain dan tempat masak juga dipisahkan untuk suku bangsa lain suku Batak menggunakan rumah suku bangsa lain yang dekat dengan mereka, hal ini dilakukan untuk menghargai suku bangsa lain yang tidak makan babi.

Selain suku bangsa lainyang mampu menghargai dan menerima kebudayaan dan tradisi suku Batak, sifat menghargai juga dilakukan oleh suku Batak dimana suku Batak sangat menghargai peraturan yang telah dibuat di Nagari Koto Baru yaitu adanya larangan perternakan babi di Nagari tersebut yang peraturan tersebut merupakan salah satu peraturan adat Minangkabau yang kental dengan falsafah Islamnya, namun suku bangsa Batak sangat menghargai peraturan tersebut dan merenerima dengan lapang dada, meskipun peraturan tersebut tidak esui dengan tradisi dan kebiasaan suku Batak demi kedamaian di Nagari Koto Baru, hal ini tergambar dari surat edaran yang dilakukan oleh kepala Nagari bahwa di Nagari Koto Baru tidak diperbolehkan berternak babi dan peraturan tersebut diterima oleh masyarakatNagari Koto Baru demi kepentingan keamanan dan kesejahteraan masyarakat Nagari Koto Baru baik suku bangsa lokal maupun suku bangsa pendatang.

\section{Kebudayaan dan Tradisi Suku Jawa}

Suku Jawa yang dikenal sebagai suku dengan jumlah terbesar di Indonesia dan tersebar ke seluruh daerah-daerah yang ada di Indonesia, ternyata juga mempunyai jumlah yang relatif banyak di Nagari Koto Baru ini, yaitu dengan jumlah lebih kurang 25 persen dari keseluruhan jumlah penduduk Nagari 
Koto Baru. Suku Jawa juga memiliki identitas dan ciri khas tersendiri dalam kebudayaan dan tradisi, dimana dalam segi bahasa suku jawa juga masih menggunakan bahasa asli mereka bahkan mereka juga mengajarkan bahasa jawanya terhadap keturunan mereka dan Bahasa Jawa ini tidak hanya digunakan oleh suku jawa sendiri namun, suku Minangkabau juga banyak yang menggunakan Bahasa Jawa karena lingkungan mereka yang mebiasakan mereka menggunakan Bahasa Jawa, hal ini terjadi karen suku Jawa di Nagari Koto Barusangat mendominasi. Meskipun demikian suku Jawa menghargai dengan suku lain yang tidak paham dengan Bahasa Jawa, seperti halnya suku Batak suku Jawa juga menggunakan Bahasa Indonesia untuk berinteraksi dengan suku bangsa lain.

Mengenai sistem religi suku Jawa di Nagari Koto Baru beragama Islam dan sebagian suku Jawa juga ada yang beragama Kristen, meskipun sebagian dari mereka ada yang berbeda keyakinan namun mereka tetap hidup damai dengan suku bangsa lain seperti halnya suku Batak yang keseluruhan sukunya beragama Kristen.

Selanjutnya kesenian suku Jawa juga sangat digemari dan disukai oleh suku bangsa lain sehingga kesenian suku Jawa memiliki organisasi dan persatuan sendiri di Nagari Koto Baru seperti persatuan Kuda Lumping hampir setiap jorong di Nagari Koto Baru terhadap persatuan tersebut, dimana yang menjadi anggota persatuan kuda lumping tidak hanyya suku Jawa namun suku Minangkabau juga ikut serta jadi anggota dan juga jadi pemain musik serta penari kuda lumping dan kesenian lainnya. Kesenian yang sering ditampilkan yaitu kuda lumping, reog, dan campur sari.Kesenian tersebut ditampilkan pada setiap acara perkawinan, sunat Rasul, dan turun mandi yang tidak hanya diadakan pada acara suku Jawa saja bahkan suku bangsa lain juga suka mengadakan acara dengan menampilkan kesenian yang dimiliki oleh suku jawa tersebut. Selain perayaan tersebut kesenian suku Jawa juga ditampilkan pada setiap acara-acara resmi nagari bahkan Kabupaten.

Selain kebudayaan yang dapat diterima dan dihargai oleh suku bangsa lain sebagian tradisi suku Jawa juga tetap dilakukan dan tetap ada di Nagari Koto Baru seperti tradisi sesajen untuk roh yang telah tiada yang masih tetap dilakukan setiap hari Jum'at Kliwon dan tradisi perkawinan suku Jawa yang masih kental dengan adat mereka juga masih ada dan tetap dilakukan. Penjelasan tersebut diperkuat oleh pernyataan dari salah seorang informan, bapak Paryanto (Jawa), 47 tahun menjelaskan bahwa,"kebudayaan suku bangsa jawa masih tetap ada di Nagari Koto Baru ini bahkan disetiap acara baik itu secara resmi, acara-acara hari-hari besar 17 Agustus, maupun acara-cara hajatan seperti pernikahan, sunat rosul dan acara turun mandi kebudayaan Jawa masih tetap digunakan dan ditampilkan, kebudayaan yang sering ditampilkan adalah kesenian kuda lumping yang anggotanya tidak hanya berasal dai Jawa saja bahkan bahkan suku Minangkabau juga berniat sebagai anggota, sebagai penari kuda lumping, dan juga sebagai pemain musiknyan dan tradisi memberi sesajen kepada roh halus juga masih kami lakukan setiah hari Jum'at Kliwon".

Pernyataan yang diberikan oleh bapak Paryanto tersebut menggambarkan bahwa masyarakat minangkabau dan suku bangsa lain sangat menghargai dan mencintai kebudayaan yang masuk ke Nagari Koto Baru sebagai kebudayaan islam, sebagai masyarakat yang mencintai kebudayaan lain masyarakat Minangkabau ikut berpartisipasi dengan ikut serta sebagai anggota dari pesatuan kuda lumping yang hampir setiap jorong ada.

\section{Kebudayaan Dan Tradisi Suku Sunda}

Suku bangsa sumda merupakan salah satu suku pendatang di Nagari Koto Baru , suku bangsa Sunda memiliki jumlak yang relatif sedikit di Nagari Koto Baru ini, yaitu dengan kurang lebih 5 persen dai keseluruhan jumlah penduduk termasuk suku bangsa Minangkabau yang merupakan penduduk asli di Nagari Koto Baru yang ada di Nagari Koto Baru . 
Kebudayaan dan tradisi suku Sunda juga sangat diterrima oleh suku bangsa lain di Nagari Koto Baru dimana dari segi bahasa yang digunakan adalah Bahasa Sunda, namun Bahasa Sunda tidakdigunakan oleh suku Sunda untuk berinteraksi dengan suku bangsa lain, meskipun demikian logat Bahasa Sunda yang terlalu cepat tersebut menjadikan suku Sunda terkenal dengan cerewetnya.

Kesenian yang masih di tampilkan di Nagari Koto Baru adalah kesenian Kirap Helaran atau disebut sisingon adalah suatu jenis kesenian tradisional atau jejis seni pertunjukan rakyat yang dilakukan dengan arak-arakan dalam bentuk helaran. Pertunjukannya kesenian tersebut ditampilkan pada acara khitanan atau acara-acara khusus seperti menyambut tamu, acara peresmian, kegiatan HUT kemerdekaan RI dan kegiatan hari-hari besar lainnya yang diadaka di Nagari Koto Baru .

\section{Kebudayaan dan Tradisi Suku Mandailing}

Suku bangsa mandailing juga merupakan salah satu suku bangsa pendatang di Nagari Koto Baru, suku bangsa mandailing ini juga memiliki jumlah yang relatif sedikit namun suku Mandailing mempeunyai jumlah yang lebih banyak dibandingkan dengan suku Sunda di Nagari Koto Baru yang ada di Nagari Koto Baru .

Suku Mandailing juga memilii identitas dan ciri khas kebudayaan tersendiri namun kebudayaan suku mandailing yidak jauh berbeda dengan suku Batak, hal ini terjadi karena daerah suku Mandailing dengan suku Batak tidak terlalu jauh yang membedakan kebudayaan suku Madailing dengan suku Batak adalah dari segi bahasa di mana suku Mandailing memiliki bahasa sendiri dalam melakukan interaksi dengan kelompok suku mereka namun tetap menggunakan Bahasa Indonesia dalam berinteraksi dengan suku bangsa lain karena bahasa yang digunakan oleh suku Mandailing sulit untuk dipahami.

Selain dari segi bahasa yang membedakan kebudayaan suku Mandailing dengan suku Batak adalah sistem religinya, dimana suku mandailing sangat kental dengan agama Islam di Nagari Koto Baru suku Mandailing terkenal dengan suku yang fanatik dan sulit untuk meneriman agama lain selain agama Islam, namun sifat fanatik yang dimiliki oleh suku Mandailing tersebut tidak menjadikan mereka untuk menjadi suku yang tidak menghargai suku bangsa lain yang ada di Nagari Koto Baru. Sifat menghargai tersebut mereka lakukan demi menjaga keamana dan ketertiban di Nagari Koto Baru. Berdasarkan tradisi perkawinan, proses perkawinan yang dilakukan oleh suku Mandailing hampir sama dengan suku Batak tetap diawali dengan upacara-upacara adat dan tetap ada acara mentor-tor dan adat perkawinannya hanya saja ada sedikit yang membedakan antara proses perkawinan Batak dengan suku mandailing yaitu tempat upacara perkawinan suku mandailing di lakukan di Masjid atau di rumah mempelai perempuan.

\section{INTEGRASI ANTAR SUKU BANGSA}

Keberhasilan masyarakat Nagari Koto Baru dalam menghindari konflik antar suku bangsa dapat juga dilihat berhasilnya masyarakat tersebut dalam mengintegrasi suku bangsanya dengan baik, dengan dibangunnya interdepedensi yang lebih rapat antara bagian-bagian dari organisasi hidup atau antara anggota dalam masyarakat. Hal ini dapat diartikan bahwa terjadi proses mempersatukan nasyarakat yang cenderung menjadikan kota yang harmonis. Proses integrasi antar suku bangsa dalam Nagari Koto Baru jugadidorong dengan adanya proses sosial yang bernentuk (1) kerjasama, Akomodasi, dan (3) Asimilasi.

\section{Proses Kerjasama Antar Suku Bangsa}

Proses kerjasama di Nagari Koto Baru diawali dengan kepercayaan masyarakat Nagari Koto Baru dalam hal kepemimpinan yang dipercayalan kepada selurug suku bangsa di Nagari Koto Baru mebjadikan nagari tersebut sebagai nagari yang terintegrasi. Integrasi tersebut dapat terjadi apabila terjadi kerjasama dengan ada kegiatan di nagari. Salah satu kegiatannya, yaitu 
gotongroyong secara teratur yang dilakukan bersama oleh seluruh suku bangsa yang ada di Nagari Koto Baru kegiatan lain yang berbentuk memperingati hari besar baik itu hari besar nasional maupuh hari keagamaan. Setiap kegiatan yang dilakukan di Nagari Koto Baru akan dilakukan musyawarah bersama dalam rapat nagari yang dihadiri oleh seluruh suku bangsa yang ada di Nagari Koto Baru.

Kegiatan gotongroyong yang dilakukan oleh masyarakat Nagari Koto Baru merupakan kegiatan yang dilakukan rutin setiap satu bulan satu kali, kegiatan gotongroyong ini dilakukan di masing-masing jorong yang ada di Nagari Koto Baru yang dilakukan oleh seluruh suku bangsa yang terdapat di jorong tersebut. Gotongroyong bulanan dilakukan dengan tujuan untuk menyatukan suku bangsa, membentuk kerukunan antar suku bangsa, dan juga untuk menjaga kebersihan di masingmasing jorong di Nagari Koto Baru.

Kegiatan lain selain gotongroyong bulanan di Nagari Koto Baru juga memiliki program kegiatan Darmawati karyawan PTPN N IV, arisan di jorong masing-masing, dan kegiatan pertemuan pemuda. Kegiatan tersebut juga merupakan kegiatan bersama yang dilakukan oleh seluruh suku bangsa yang ada di Nagari Koto Baru, dimana kegiatan ini dilakukan untuk menjalin silatuhrahmi dan hubungan antar suku bangsa.Nagari Koto Baru bukan hanya melakukan kegiatan-kegiatan kebersamaan untuk menghindari konflik si nagarinya, namun Nagari Koto Baru juga menerapkan sistem kebersamaan pada selru masyarakat Nagari Koto Baru dimana sistem tersebut diterapkan agar masyarakat di Nagari Koto Baru dapat terjaga kesejahteraannya, dan menjalani suatu aktifitas dalam suasana damai. Sistem yang diterapkan oleh nagari tersebut merupakan salah satu strategi Nagari Koto Baru dalam menghindari konflik dengan cara masing-masing pemimpin dan tokoh masyarakat saling berhubungan dan memberi informasi apabila ada hal-hal yang terjadi yang tidak sesuai dengan keinginan Nagari
Koto Baru, seoerti konflik antar suku bangsa.

\section{Proses Akomodasi}

Akomodasi merupakan upaya untuk mencapai penyelesaian dari suatu pertikaian atau konflik oleh pihak-pihak yang bertikai yang mengarah pada kondisi atau keadaan selesainya suatu konflik atau pertikaian tersebut (Setiadi, 2011:79). Nagari Koto Baru melakukan akomodasi dengan cara melakukan rapat nagari rutin setiat satu bulan satu kali dan membentuk lembaga adat penyelesaian konflik untuk menghindari agar tidak terjadi konflik.

Rapat nagari yang rutin dilakukan setiap satu bulan dan setiap penyambutan acara-acara besar baik acara nasional maupun acara keagamaan dihadiri oleh wali nagari, masing-masing kepala jorong, pemuka adat, ketua RT/RW pada setiap jorong, masingmasing ketua pemuda setiap jorong, pemuka adat dan ketua keamanan, hal ini dilakukan demi tercapainya kesepakatan bersama dan tidak ada kesenjanagan sosial dengan adanya keberagaman suku bangsa di Nagari Koto Baru, setiap keputusan yang diputuskan secara bersama dengan cara musyawarah harus dihargai dan dilaksanakan.

Jabatan sebagai kepala jorong dipercayakan kepada suku Minangkabau dan Suku jawa karena suku tersebut merupaka suku terbabyak di Nagari Koto Baru, ketua adat dipercayakan kepada suku Minangkabau karena mereka yang mengetahui selik-beluk nagari, Ketua RT/RW dan pemuda dipercayakan kepada suku Jawa, Batak, dan Sunda hal ini dilakukan demi kenyamanan setiap suku bangsa yang ada di Nagari Koto Baru seperti suku bangsa Batak yangmemiliki kecenderungan tinggal dengan kelompok sendiri, ketua keagamaan dipercayaka kepada siku Mandailing karena suku Mandailing merupakan suku yang sangat kentak dengan relegius dan sesuai dengan filsafah yang ada di Ranah Minangkabau, sedangkan ketua keamana dipercayakan kepada suku bangsa Batak karena suku Batak merupakan salah satu suku yang sangat tegas dalam melakukan segala hal 
dengan watak kasarnya.Musyawarah bersama selalu dilakukan oleh masyarakat Nagari Koto Baru pada setiap kegiatan kegiatan yang akan dilakukan agar terjalin kerukunan pada setiap suku bangsa yang ada di Nagari Koto Baru, hal ini sesuai dengan pernyataan ketua wali nagari dalam kata sambutannya setiap musyawarah berlangsung, yang selalu mengingatkan bahwa, sebagai masyarakat yang majemuk baik itu dari suku bangsa maupun agama hendaknya masyarakat kita saling mengharai, bahu membahu, dan dapat selalu hidup rukun.

Berdasarka kata sambutan yang dikemukakan oleh kepala nagari tersebut menggambarkan bahwa musyawarah tersebut dilakukan untuk menghormati setiap keputusan yang dilakukan oleh pemimpin nagari dengan menghargai keputusan yang diputuskan bersama dengan adanya musyawarah bersama.Setiap suku mempunyai identitas sendiri, baik identitas karena bawaan keturunan ataupun karena pengaruh budarya (kultural) yang membedakannya dengan suku lain. Young mengatakan bahwa, identitas etnis adalah proses integrasi sosial, disintegrasi, dan kristalisasi identitas etnis merupakan proses yang dinamis. Kekuatan-kekuatan seperti urbanisasi industrialisasi dan sekularisasi tidak secara otomatis merusak identitas kelompok etnis tetapi urbanisasi itu sendiri bisa merupakan faktor kuat yang menggerakkan pluralisme kultural (Pelly, 1998).

\begin{tabular}{llr}
\multicolumn{2}{c}{ Berdasarkan penjelasan yang } \\
dikatakan oleh
\end{tabular} walaupunnagari yang dihuni oleh banyak suku, namun masing-masing kelompok suku masih tetap dengan identitas sukunya masing-masing atribut-atribut yang digunakan untuk mengkomunikasikan identitas dirinya dari suku tertentu tersebut terlihat dari bahasa dan kesenian-kesenian yang masih digunakannya.Dari segi bahasa, masing-masing suku masih tetap menggunakan bahasa sukunya masingmasing.dan mereka tetap mengajarkan bahasa sukunya tersebut kepada anakanaknya walaupun anak-anaknya itu sudah dilahirkan dan dibesarkan di Nagari Koto Baru.

Selain melakukan rapat nagari yang dilakukan rutin setiap satu bulan sekaliuntuk melakukan musyawarah dalam kegiatan bersama. Nagari Koto Baru juga mempunyai sttrategi lain dalam mempertahankan nagarinaya agar tidak timbul konflik, strategi yang digunakan untuk menghindari konflik yang dilakukan di Nagari Koto Baru yaitu dengan cara menerapkan sistem kebersamaan dengan saling memberi informasi antara jorong yang satu denga jorong lainnya yang terdapat di Nagari Koto Baru. Kegiatan saling memberi informasi tersebut diawali dari adanya peraturan nagari untuk mendirikan poskamling pada setiap jorong dan menerapkan wajib ronda terhadap seluruh warga pada masing-masing jorong, dimana seluruh wagga tersebut mencakup seluruh suku bangsa, kegiatan ronda tersebut dilakukan setiap malam dengan cara bergiliran. Kegiatan ronda tersebut akan mempermudah warga untuk mengetahui hal-hal yang terjadi di jorongnya dan akan mewujudkan keamanan dan ketertiban di Nagari Koto Baru.

Selain saling memberika informasi dalam penerapan sistem jebersamaan juga dilakukan dengan cara saling menegur apabila terdapat salah satu warga Nagari Koto Baru yang melanggar aturan yang telah ditetapkan bersama, meskipun warga tersebut bukan merupakan salah satu dari warga jorong tempat mereka melakukan pelanggaran maka tetap harus ada teguran dan tindakan dari jorong setempat.

Tindakan yang dilakukan oleh jorong setempat terhadap warga yang melanggar peraturan nagari tidak dilakukan secara sepihak namun dilakukan dengan cara menyerahkan warga tersebut kepada kepal jorong untuk kemudian ditindaklanjuti ke nagari atau lembaga penyelesaian konflik, hal ini dilakukan agar menjaga agar tidak ada salah paham antara jorong satu dengan jorong lain dan agar tidak salah langkah dalam mengambil keputusan untuk memberi sanksi terhadap warga yang bermasalah 
tersebut.Sistem kebersamaan tersebut dapat terjadi karena tingginya jiwa persaudaraan antara suku bangsa yang terdapat di Nagari Koto Baru, hal ini tergambar dari cara mereka yang sangat melindungi suku bangsa lain agar terhindar dari konflik, dimana pada tahun 2010 terdapat argumen-argumen dari luar Nagari Koto Baru yang merupaka salah satu oknum pemerintahan dari luar daerah kabupaten Pasaman Barat (polisi) yang menyarankan agar suku Batak dilarang tinggal dan bermukim di Nagari Koto Baru dengan alasan keyakinan suku Batak yang berbeda dengan falsafah islam yang diterapkan di Nagari Koto Baru, oknum tersebut menganggap bahwa dengan adanya suku bagsa Batak akan merusak falsafah Islam yang ada di nagari tersebut, hal ini tergambar dari adanya pernyataan dari salah satu informan Bapak Simarmata (Batak) 51 tahun, yang menyatakan bahwa:

"sebenarnya dulu ada salah satu oknum pemerintah dari luar daerah Nagari Koto Baru yang melarang kami orang Batak untuk tinggal di nagari ini karena kami berbeda agama dengan mereka, namun kami dilindungi oleh masyarakat Minangkabau itu sendiri kalau mereka sampai percaya dengan orang yang datang dari luar itu mungkin nagari ini juga akan mengalami konfli antar suku bangsa bahkan agama disini sebab yang beragama Kristen bukan saja orang Suku Batak akan tetapi suku Jawa juga ada yang beragama Kristendi nagari ini, contohnya saja Jorong Mahakarya penduduknya banyak orang jawa tetapi di sana mayoritas agamanya Kristen".

Pernyataan tersebut diperkuat oleh pernyataan salah satu informan yang merupakan masyarakat suku Minangkabau yaitu bapak Zainal (Minangkabau) 53 tahun, dimana bapak Zainal merupakan kepala jorong Ophir yang merupakan salah satu jorong dengan jumlah penduduk suku Nataknya terbanyak, yang menyatakan bahwa,"di Nagari Koto Baru ini, sistem kekeluargaannya tinggi, suku apapun yang tinggal di nagari ini tetap kami anggap saudara yang bisa kami bawa untuk musyawarah yang bisa menerima setiap keputusan yang akan diambil bersama. Maka dari itu kalau ada orang dari luar yang tidak suka dengan salah satu suku nagari ini kami akan selalu membantu mereka dan kami akan selalu melindungi mereka selama mereka dalam posisi yang benar. Pernah sekitar tahu 2010ada orang yang tidak suka suku Batak tinggal di nagari ini denan alasan beda keyakinan, tetapi menerut kami itu tidak ada masalah selama masyarakat Batak bisa mengikuti dan menaati peraturan di sini makanya kami lindungi suku Batak dan kami bela mereka".

Pernyataan tersebut menggambarkan bahwa di Nagari Koto Baru memiliki jiwa persaudaraan yang tinggi sehingga walaupun ada tukang propoganda yang dapat menciptakan permusuhan di nagari tersebut mereka dapat mencegah dan menghindari konflik yang akan terjadi serta dapat menjadikan masyarakat Nagari Koto Baru lebih terintegrasi lebih baik lagi.

Strategi Nagari Koto Baru dalam mengontrol suku bangsa tertentu dengan cara dibentuknya lembaga adat dalam menyelesaikan konflik, lembaga ini dipimpin oleh kepala wali nagari langsung dan masing-masing jorong di koordinasi oleh kepala jorong, keberanggotaan tokoh-tokoh masyarakat disetiap jorong yang menurut mereka lebih memiliki pengaruh besar (dituakan) di masing-masing jorongdan ketua pemuda masing-masing jorong, pemilihan anggota lembaga adat ini dilakukan dengan alasan agar setiap informasi konflik yangterjadi pada masing-masing jorong dapat disampaikan langsung ke lembaga adat penyelesaian konflik tersebut.

Lembaga adat dalam penyelesaian konflik saja namun juga untuk mengontrol kriminalitas yang ada di Nagari Koto Baru demi keamana dan ketertiban di nagari tersebut, dimana konflik yang akan dan sudah dikontrol oleh lembaga adat dalam penyelesaian konflik ini adalah konflik SARA 
diantaranya konflik kelompok, konflik antar suku bangsa, dan konflik antar agama.

Dalam menjaga keamanan dan ketertiban Nagari Koto Baru lembaga adat dalam penyelesaian konflik ini melakukan pertemuan setiap satu bulan sekali setiap tanggal 16 dengan tempat bergiliran disetiap jorong yang ada di Nagari Koto Baru, pertemuan ini dilakukan untuk mengevaluasi apakah telah terjadi konflik di nagari atau masing-masing jorong, dalam pertemuan ini mereka akan saling berbagi informasi yang telah mereka peroleh dari warga pada masing-masing jorong dalam hal keamanan dan ketertiban masyarakat Nagari Koto Baru. Pertempuan lembaga adat tersebut bukan hanya diadakan rutin sebualan sekali namun pertemuan tersebut akan diadakan mendadak apabila terjadi konflik dan kriminalitas di Nagari Koto Baru, penjelasan tersebut diperkuat dengan pernyataan salah satu informan yang juga merupakan salah satu jorong di Nagari Koto Baru bapak Zulkarnain (Minangkabau) 37 tahun, yang menyatakan bahwa:

"untuk menghindari konflik, hal-hal yang berhubungan dengan kriminalitas dan segala sesuatu yang akan menimbulkan kerusuhan di nagari, kami membentuk lembaga adat dalam penyelesaian konflik yang berfungsi mengatur ketertiban nagari, menyelesaikan konflik dan masalah-masalah lainnya".

Kasus yang pernah diselesaikan oleh lembaga adat dalam penyelesaian konflik adalah kasus yang berhubungan dengan kriminalitas yaitu kasus perkelahian antar keluarga, kasus pembunuhan, dan kasus pencurian, selain kasus yang berhubungan dengan kriminalitas, kasus yang pernah diselesaikan oleh lembaga ini adalah kasus kenakalan remaja dan penyakit masyarakat seperti kasus narkoba yang dilakukan oleh kalangan pelajar dan kasus perjudian.

Berdasarkan hasil penelitian yang dilakukan, konflik antar suku bangsa di Nagari Koto Baru belum pernah terjadi, namun di Jorong Sungai Talang yang mayoritas penduduknya adalah suku Minangkabau dan joronh Mahakarya yang mayoritasnya penduduk Jawa hampir timbul konflik karena adanya kesalapahaman antar suku Minangkabau dan suku Jawa yang mendapa isu-isu dari luar. Strategi yang digunakan oleh lembaga adat dalam penyelesaian konflik berfungsi untuk menghindari konflik yang akan terjadi di Nagari Koto Baru hal ini juga dijelaskan oleh salah satu informan, bapak Paryanto (Jawa) 47 tahun yang menyatakan bahwa:

"Di sini pernah ada beberapa kasus diselesaikan oleh lembaga adat dan prosesnya cukup lama dan menguras tenaga, namun bukan konflik antar suku bangsa. Memang beberapa waktu lalu hampir terjadi konflik antar suku Jawa dengan Suku Minang, tapi alhamdulillah lembaga adat dalam penyelesaian konflik ini bisa mencegahnya".

Strategi tersebut dilakukan dengan cara mempertemukan kedua belah pihak baik itu dari jorong Sungai Talang maupun dari jorong Mahakarya dan memberikan arahan kepada masingmasing yang akan berkonflik, hal ini dilakukan agar masing-masing jorong memahami bahwa onflik itu tidak perlu terjadi di Nagari Koto Baru penjelasan ini diperkuat oleh pernyataan bapak Nasrizal (42 tahun):

"untuk menghindari konflik antara suku Minangkabau dengan suku Jawa tersebut dengan cara kami pertemukan orang-orang yang berpengaruh di masing-masing jorong trus kami beri arahan agar hati-hati mencerna komunikasi yang mengarah ke perpecahan, jika mereka tidak bisa diarahankan kami akan bertindak lebih tegas".

Tindakan mempertemukan kedua belah pihak yang bermasalah memang sering dilakukan oleh lembaga adat ini dan pada dasarnya arahan yang mereka berikan untuk tidak melakukan konflik selalu dipatuhi oleh kedua belah pihak.

Selain tindakan mempertemukan kedua belah pihak dalam menyelesaikan permasalahan lembaga adat 
penyelesaian konflik ini juga memiliki program untuk memberikan sanksi kepada orang yang tidak bisa mematuhi peraturan dan tidak bisa diberi pengarahan, dengan kata lain setelah lembaga adat ini mempertemukan kedua belah pihak namun tidak brhasul dan masih terjadi konflik maka tindakan selanjutnya yang akan dilakukan oleh lembaga adat ini adalah dengan cara melakukan kerjasama dengan aparat hukum untuk menyelesaikan konflik yang terjadi.

Program lembaga penyelesaian konflik lainnya yang telah diterapkan di Nagari Koto Baru adalah program pengadaan fasilitas poskamling di setiap jorong dan masing-masing jorong menerapkan adanya piket ronda dimana yang berpartisipasi dalam melakukan kegiatan ronda tersebut adalah warga laki-laki di masing-masing jorong. Prpgram ini dilakukan agar masingmasing jorong dengan mudah mendapatkan informasi tentang keamanan dan ketertiban jorongnya.

\section{Proses Asimilasi}

Asimilasi merupakan proses sosial yang ditandai dengan adanya upayaupaya mengurangi perbedaan-perbedaan antara orang-perorangan atau antar kelompok sosial yang diikuti pula usahausaha untuk mencapai kwsatuan tindakan, sikap, dan proses-proses mental dengan memperhatikan kepentingan bersama (Setiadi \& Kolip, 2011)

Dalam penelitian ini proses asimilasi ditandai dengan adanya perkawinan antara suku bangsa yang satu dengan suku bangsa yang lain. Perkawinan suku bangsa yang berbeda di Nagari Koto Baru berupaya untuk mengurangi perbedaan antara suu bangsa yang satu dengan suku bangsa yang lainnya. Perkawinan antara suku bangsa yang berbeda tersebut bahkan akanmempersatukan dua suku bangsa yang berbeda dengan cara saling menghargai antara satu suku bangsa dengan suku bangsa lainnya.

Perbedaan antara suku bangsa yang ada di Nagari Koto Baru akan menjadi perkawinan yang akan diadakan oleh berbeda suku bangsa di Nagari Koto Baru terintegrasi dengan baik dan akan membantu Nagari Koto Baru untuk menghindari koflik, karena dengan adanya perkawinan yang berbeda suku bangsa tidak hanya menyatukan keluarga saja namun juga dapat menyatuka kedua suku bangsa yang berbeda kebudayaan dan tradisi tersebut.

Berdasarkan data yang diperoleh jumlah penduduk yang melakukan perkawinan yang berbeda suku pada tahun 2010 sampai 2013 yaitu, tahun 2010 berjumlah 115 pasang, tahun 2011 berjumlah 69 pasang, tahun 2012 berjumlah 69 pasang, dan tahun 2013 berjumlah 36 pasang untu masingmasing suku bangsa yang melakukan perkawinan yang berbeda suku bangsa, untuk lebih jelas data tersebut akan disajikan melalui Tabel di bawah ini:

Tabel 1

Data Perkawinan Antar Suku Bangsa di Nagari Koto Baru 2010-2013

\begin{tabular}{|c|c|c|c|c|c|c|}
\hline \multirow[b]{2}{*}{ No } & \multirow{2}{*}{$\begin{array}{c}\text { Perkawin } \\
\text { an Antar } \\
\text { Suku } \\
\text { Bangsa }\end{array}$} & \multicolumn{4}{|c|}{ Tahun } & \multirow[b]{2}{*}{$\begin{array}{l}\text { Jum } \\
\text { lah }\end{array}$} \\
\hline & & 2010 & 2011 & 2012 & 2013 & \\
\hline 1 & $\begin{array}{l}\text { Minang \& } \\
\text { Jawa }\end{array}$ & 35 & 30 & 34 & 20 & 119 \\
\hline 2 & $\begin{array}{l}\text { Minang \& } \\
\text { Jawa }\end{array}$ & 11 & 4 & 9 & - & 24 \\
\hline 3 & $\begin{array}{l}\text { Minang \& } \\
\text { Mandailing }\end{array}$ & 8 & 10 & 12 & 2 & 32 \\
\hline 4 & $\begin{array}{l}\text { Minang \& } \\
\text { Batak }\end{array}$ & - & - & - & - & - \\
\hline 5 & $\begin{array}{l}\text { Jawa \& } \\
\text { sunda }\end{array}$ & 28 & 11 & 14 & 19 & 62 \\
\hline 6 & $\begin{array}{l}\text { Jawa \& } \\
\text { Mandailing }\end{array}$ & 10 & 6 & - & - & 16 \\
\hline 7 & $\begin{array}{l}\text { Jawa \& } \\
\text { Batak }\end{array}$ & 15 & 3 & - & - & 18 \\
\hline 8 & $\begin{array}{l}\text { Sunda \& } \\
\text { Mandailing }\end{array}$ & - & - & - & - & - \\
\hline 9 & $\begin{array}{l}\text { Sunda } \\
\& \text { Batak }\end{array}$ & 8 & 5 & - & - & 18 \\
\hline 10 & $\begin{array}{l}\text { Mandailing } \\
\text { \& Batak }\end{array}$ & - & - & - & - & - \\
\hline \multicolumn{2}{|c|}{ Jumlah } & 115 & 69 & 69 & 36 & 289 \\
\hline
\end{tabular}

Sumber : Surat Pengantar NA Nagari Koto Baru 2010-2013 (diolah) 
Mencermati tabel 1 perkawinan antara suku bangsa dalam kurun waktu 2010-2013 tertinggi terjadi pada suku bangsa Minangkabau denga suku bangsa Jawa sebanyak 119 perkawinan. Sedangkan nomor dua tertinggi dalam kuru waktu yang sama terjadi pada suku bangsa jawa dengan suku bangsa Sunda sebanyak 62 perkawinan dan nimor tiga tertinggi terjadi pada suku bangsa minangkabau dengan suku bangsa Sunda sebanyak 24 perkawinan. Berdasarkan tabel 1 juga ditemukan bahwa dalam kuru waktu yang sama tidak terjadi perkawinan antara suku bangsa Minangkabau dengan uku bangsa Batak, begitu juga suku bangsa Mandailing dengan suku bangsa Sunda, serta suku bangsa Mandailing dengan suku bangsa Batak. Meskipun demikian berdasarkn informasi ydari kepala jorong Ophir yang merupakan salah satu jorong yang terdapat suku banga yang beraneka ragam, Nagari Koto Baru tidak pernah berkonflik secara manifes.

Penelusuran lebih lanjut terhadap suku bangsa yang tidak pernah melakukan perkawinan antara suku bangsa yang berbeda diperoleh informasi dari kantor wali nagari bahwa ada hal-hal tertentu yang menjadi pembatas antara kelompok tersebut sehingga mereka gidak menjalani proses asimilasi tersebut. Salah satu faktor penyebnya adalah faktor kebiasaan suku bangsa tertentu yang dianggap negatif oleh suku bangsa tertentu,isamping itu ada faktor perbedaan agama yang menjadi penghambatnya.

Meskipun proses asimilasi pada suku bangsa tertentu mengalami kemacetan yang disebabkan karena adanya faktor kebiasaan dan faktor agama mereka tetap terintegrasi dalam sistem sosial masyarakat di Nagari Koto Baru dalam konteks norma sosial uang berlaku di nagari tersebut. Halini dapat dikatakan bahwa strategi lain mereka menghindari konflik adalah dengan cara mematuhi norma sosial yang ada dalam Nagari Koto Baru. Salah satu norma sosial yang mereka patuhi adalah bahwa mereka meliliki konsensus dalam menyatakan identitas diri mereka bahwa "kami orang indonesia".
Mencermati yang menjadi asumsi dan teori struktural fungsional bahwa masyarakat selalu menjaga kestabilan dan didukung oleh adanya konsensus sangat terlihat dalam masyarakat Nagari Koto Baru, hal ini menunjukan bahwa proses adaptation (adaptasi), goal attanment (pencapaian tujuan), integration (integrasi), latency (latensi atau pemeliharaan pola) berjalan sebagaimana mestinya.

\section{KESIMPULAN}

Beberapa hal yang bisa di simpulkan dari penelitian ini adalah gambaran suku bangsa di Nagari Koto Baru dimana suku asli yang ada di Nagari Koto Baru adalah suku Minangkabau. Penyebab terjadinya konflik di Nagari Koto Baru adalah mansyarakat multikultural, dua faktor yang dapat menghindari konflik di Nagari Koto Baru yaitu faktor solidaritas msayarakat Nagari Koto Baru yang sangat tinggi dan faktor perkawinan antara suku bangsa yang satu dengan suku bangsa lainnya.

Strategi masyarakat multikultural di Nagari Koto Baru dalam menghindari konflik yaitu diawali dari bagaimana masyarakat asli Minangkabau memahami, menerima, dan mampu menghargai setiap kebudayaan dan tradisi yang dibawa oleh suku bangsa pendatang di Nagari Koto Baru. Keberhasilan masyarakat Nagari Koto Baru dalam menghindari konflik antara suku bangsa juga dapat dilihat dari keberhasilan masyarakat dalam mengintegrasikan suku bangsanya dengan baik dengan dibangunnya interdepedensi yang lebih rapat antar anggota masyarakat. Proses integrasi antar suku bangsa dalam Nagari Koto Baru juga didorong dengan adanya proses sosial yang berbentuk kerjasama, akomodasi dan asimilasi.

\section{DAFTAR PUSTAKA}

Fathoni, A. (2006). Antropologi Sosial Budaya Suatu Pengantar. Jakarta: Rineka Cipta.

Firdaus, F. (2006). Pendidikan Multikultural Untuk Menata Kehidupan Masyarakat Indonesia yang Multikultural. Jurnal Sigai, VII(2), 1-16.

Firdaus, F. (2012). Relasi Etnik dan Identitas Kewargaan di Kota Binjai. In H. Budiman (Ed.), Kota-Kota di Sumatra; Enam Kisah Kewargaan dan Demokrasi 
(pp. 133-190). Jakarta: The Interseksi Foundation.

Koentajaraningrat. (1996). Pengantar Ilmu Antropologi. Jakarta: Rineka Cipta.

Nasikun. (1984). Sistem Sosial Indonesia. Jakarta: CV Rajawali.

Pelly, U. (1998). Urbanisasi dan Adaptasi: Peranan Misi Budaya Minangkabau dan Mandailing. Jakarta: LP3ES Indonesia.

Ritzer, G. (2012). Teori Sosiologi (Dari Sosiologi Klasik Sampai Perkembangan Terakhir Post Modern). Yogyakarta: Pusataka Pelajar.
Setiadi, E., \& Kolip, U. (2011). Pengantar Sosiologi Pemahaman Dan Gejala Permasalahan Sosial. Bandung: Kencana.

Sumarsono, S. D. (2005). Pendidikan Kewarganegaraan. Jakarta: Pt Gramedia Utama.

Suparlan, P. (2004). Hubungan Antar Suku Bangsa. Jakarta: IPKIk, UI.

Wirawan. (2010). Konflik dan Manajemen Konflik ( Teori, Aplikasi, dan Penelitia). Jakarta: Salembah Humanika. 


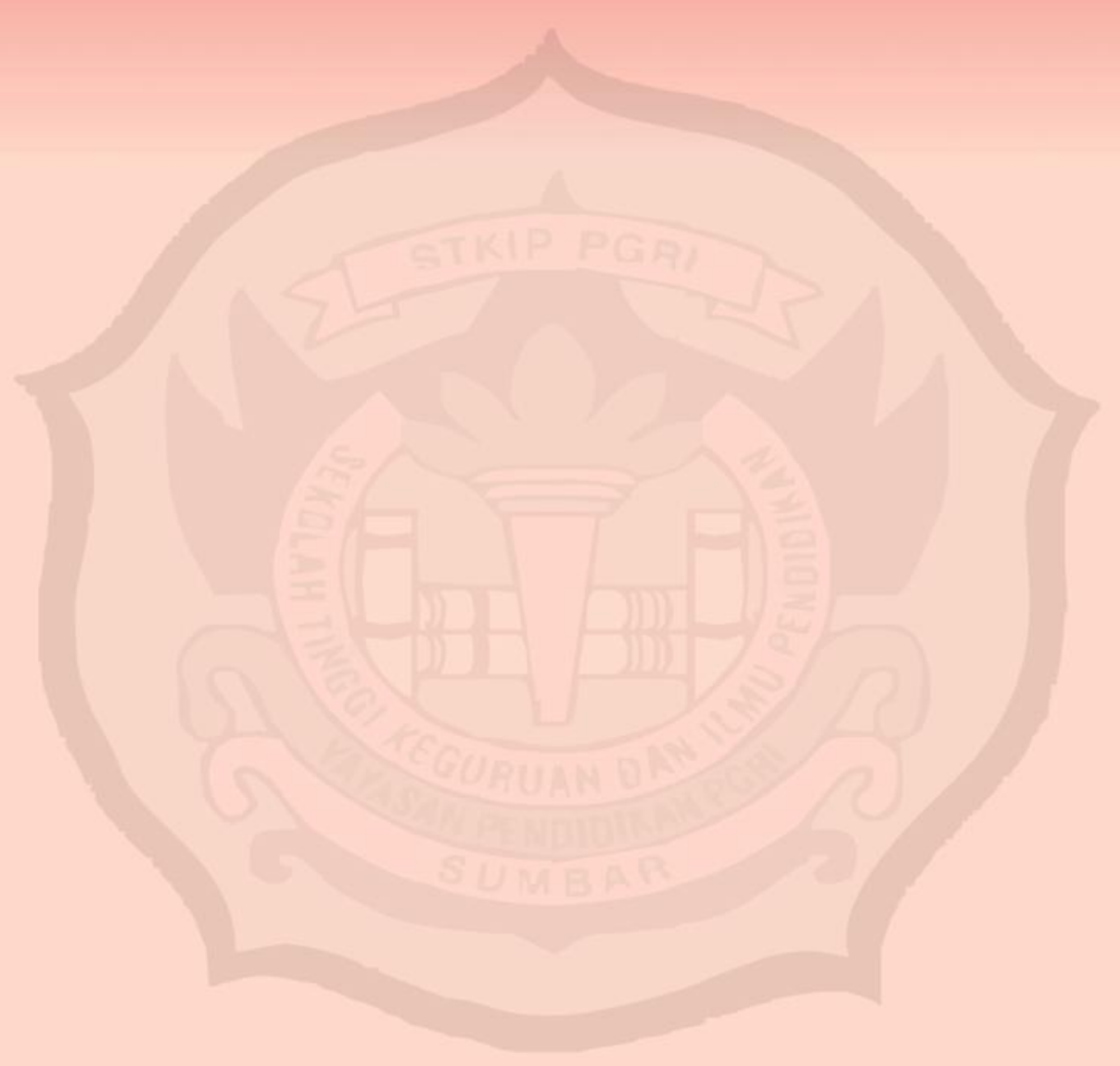

Penerbit :

Laboratorium Program Studi Pendidikan Sosiologi, STKIP PGRI Sumatera Barat

Kampus STKIP PGRI, Jl. Gunung Pangilun, Padang, Sumatera Barat

Email : redaksimamangan@gmail.com 